\title{
Stimulation of Genital Eversion in the Land Snail Helix aspersa by Extracts of the Glands of the Dart Apparatus
}

\author{
DANIEL J.D. CHUNG \\ Division of Biological Sciences, and Museum of Zoology, University of \\ Michigan, Ann Arbor, MI 48109
}

\begin{abstract}
The dart apparatus, used during courtship in some groups of hermaphroditic land snails, has long been assumed to have a "stimulatory" effect on the mating partner, though how stimulation occurs and exactly what function it serves has never been determined. In this study, extracts of the mucous glands of the dart apparatus of the land snail Helix aspersa were injected into conspecifics and into a related snail, Cepaea nemoralis, in order to test the hypothesis that the dart is used to achieve inflow of bioactive mucous gland secretions into the darted snail. Helix aspersa injected with the extract responded by everting their terminal genitals; eversion normally takes place during courtship and mating. Boiling the extract increased the bioactivity. Pronase-treated extract lost bioactivity, and gel filtration of the boiled extract indicated that the active substance has a molecular weight of about 5,000. The active substance may be a polypeptide. Cepaea nemoralis also everted their genitals when injected with the boiled Helix extract. The active substance appears to be a contact sex pheromone, the second such pheromone in a pulmonate land snail for which experimental evidence has been obtained.
\end{abstract}

Accessory organs in the terminal genitalia of the hermaphroditic land snail order Stylommatophora (reviewed by Tompa, '84) include calcareous or chitinous spears or darts that are thrust into the mating partner during courtship. About 11 of the 65 families of pulmonate land snails possess a dart apparatus, comprising a dart held in a dart sac and associated glands (Tompa, '80). In addition, at least two families of opisthobranchs possess darts (see Pruvot-Fol, '60; Boss, '82). In the Euthyneura (pulmonate snails and sea slugs), a dart apparatus may have evolved independently in at least seven different major lineages. Because of its use in courtship, it has long been assumed that the dart is a "stimulatory" device in courtship and mating (see Dorello, '25; Bornchen, '67; Tompa, '84 for reviews), though this has never been proven.

The hypothesis that the dart is used to stimulate the courting partner mechanically and thereby induce mating is very old (e.g. see Moquin-Tandon, 1855; Cooke, 1895; Meisenheimer, '07). Goddard ('62) has suggested from experiments on isolated penis sheaths of Helix aspersa that damage of tissue by the dart might cause increased tonus of the penial muscles.

The hypothesis that the mucous glands associated with the dart apparatus ( = dart glands or multifid glands) might secrete stimulatory substances during courtship has been advanced by Dorello ('25) and Bornchen ('67). Dorello ('25) found that $H$. aspersa injected with secretions of the mucous glands contorted their bodies and showed, after dissection, increased stiffening of the penis. Bornchen ('67) found that extract of the mucous glands of $H$. pomatia increased the frequency and amplitude of the heart beat. However, Goddard ('62) found no effect of mucous gland extract on contraction of a penial sheath preparation of $H$. aspersa. Other hypotheses on the function of the mucous glands include: lubrication for the dart and genitals, formation of the egg shell, and formation of the dart (Meisenheimer, '12; Moquin-Tandon, 1855; also see Bornchen, '67 and Tompa, '84 for reviews). It is now known that the mucous glands do not form either egg shell or the dart.

In recent observations on mating behavior in helicids, Lind ('76), Jeppesen ('76), and 
Giusti and Lepri ('80) did not observe any stimulation of courtship or any facilitation of mating by receipt of a dart. Lind ('76) observed that snails receiving a dart were more likely to break off courtship than those not receiving a dart, and he suggested that dart shooting might test the mating tendency of the partner.

Though darts may wound a partner, the elaborate structure of the dart apparatus suggests that it serves some adaptive function or functions. Tompa ('80, '84) suggested that dart receipt might stimulate egg maturation and release in a snail; dart shooting might thereby help the dart shooter to fertilize the eggs of its partner. Diver ('40) believed that darts evolved as a reproductive isolation mechanism. Though there is little direct evidence for Diver's hypothesis, Webb ('51) cited a single instance of the death of a Helminthoglypta caused by receiving a dart from a non-conspecific when they attempted to mate.

This paper presents experiments involving injections of whole mucous gland extract and also of fractionated components of the gland extract into Helix aspersa in order to test the hypothesis, first proposed by Dorello ('25), that the dart is used for inoculation of a stimulatory substance from the mucous glands into the mating partner.

\section{MATERIALS AND METHODS Materials}

Live adults of Helix aspersa were obtained from California through College Biological Supply Co. (Escondido, California). Individual snails were isolated in small plastic containers lined with moist soil and fed carrot slices ad libitum. The snails were kept at $21^{\circ}$ to $26^{\circ} \mathrm{C}$ on a $12-\mathrm{hr}$ light: $12-\mathrm{hr}$ dark cycle throughout the year. Only healthy active adults isolated for at least two weeks were used for injections.

\section{Preliminary assays}

Unboiled and boiled mucous gland extracts and unboiled extracts of dart sac, penis, and mantle collar were injected in volumes of 0.1 to $0.7 \mathrm{ml}$ and at doses varying from 0.9 to $23.7 \mathrm{mg}$ wet $\mathrm{wt}$ - of tissue extracted $/ \mathrm{g}$ snail (including shell) to determine differences between the effects of mucous gland extract and other tissue extracts. Mucous glands, penes, dart sacs (plus dart), and pieces of mantle collar were excised from donors, collected on ice and weighed. The tissues were then ground in water or in either Bohuslav's ('33) or Roach's ('63) saline in a glass tissue grinder. The unboiled homogenates were injected either fresh or after centrifuging for five minutes in a clinical centrifuge to remove large cellular debris. Boiled mucous gland extract was prepared by boiling for five minutes after centrifugation and was injected after it had cooled to room temperature. Injections were made into the hemocoel of crawling snails through the upper left side of the headfoot with a 25 gauge needle. Injection of the "nuchal" region of the snail minimized wound response (withdrawal into the shell and bleeding).

\section{Preliminary characterization of active substance}

Unboiled mucous gland extract and boiled extracts of dart sac, penis, mantle collar, and brain were injected, and the results were compared to the results of boiled mucous gland injections. Non-tissue control injections of distilled water, or Bohuslav's or Roach's saline, and of solutions of the neurotransmitters acetylcholine and 5-hydroxytryptamine were also performed. Acetylcholine and 5-HT occur naturally in the brain of Helix aspersa (Kerkut and Cottrell, '63). Attempted extraction of the active substance with chloroform and treatment of the mucous gland extract with nonspecific protease (Pronase), DNase, and RNase were also carried out.

Tissues were extracted from adult donor snails that had been kept in isolation for at least two weeks. The tissues were excised, collected, ground; and the extracts were injected as described above. The "dart sac" tissue used included only the inner tissue lining of the dart sac and the calcareous dart. Doses of the different tissue extracts were chosen so that the results from the different extracts would be comparable. The "standard dose" (Sd) of an organ extract was that which would be equivalent to injecting a snail of average weight with an average-sized organ from a donor. For mucous glands, the standard dose was $28.5 \mathrm{mg}$ mucous gland (wet wt tissue extracted) per $6.3 \mathrm{~g}$ snail (including shell), or $4.5 \mathrm{mg} / \mathrm{g}$. Average weights of penis, dart sac (inner lining + dart), and brain were obtained to give the standard doses shown in Table 1 . The dose for boiled mantle collar was the only dose not standardized in this way and was less than one mantle collar per injected snail; a full dose would have been too 
TABLE 1. Results of second series of bioassay injections on Helix aspersa

\begin{tabular}{|c|c|c|c|c|}
\hline \multirow[b]{2}{*}{$\begin{array}{l}\text { Extract or } \\
\text { solution }\end{array}$} & \multirow[b]{2}{*}{$\begin{array}{l}\text { Dose } \\
(\mathrm{mg} / \mathrm{g})\end{array}$} & \multicolumn{3}{|c|}{ Response } \\
\hline & & Ro & $\begin{array}{c}\text { > R0: } \\
\text { (R1-R2-R3-R4) }\end{array}$ & Other ${ }^{a}$ \\
\hline \multicolumn{5}{|l|}{ Mucous gland } \\
\hline Boiled & 4.5 & 4 & $\begin{array}{l}26 \\
(1-4-20-1)\end{array}$ & $\mathrm{P}, \mathrm{D}$ \\
\hline Boiled, 1/2 volume & 4.5 & 0 & $\begin{array}{l}5 \mathrm{NS}^{\mathrm{b}} \\
(1-0-4-0)\end{array}$ & $\mathrm{P}, \mathrm{D}$ \\
\hline Unboiled & 4.5 & 14 & $\begin{array}{l}5 * * c \\
(4-1-0-0)\end{array}$ & $\mathrm{P}, \mathrm{D}$ \\
\hline $\begin{array}{l}\text { Chloroform fraction } \\
\mathrm{H}_{2} \mathrm{O} \text { fraction }\end{array}$ & $\begin{array}{l}4.5 \\
4.5\end{array}$ & $\begin{array}{r}13 \\
6\end{array}$ & $\begin{array}{l}0 * * \\
9 \text { NS } \\
(2-0-5-2)\end{array}$ & $\begin{array}{l}\mathrm{P} \\
\mathrm{P}, \mathrm{D}\end{array}$ \\
\hline $\begin{array}{l}+ \text { Pronase } \\
+ \text { DNase and } \\
\text { RNase }\end{array}$ & $\begin{array}{l}4.5 \\
4.5\end{array}$ & $\begin{array}{r}12 \\
2\end{array}$ & $\begin{array}{l}0 * * \\
3 \text { NS } \\
(0-1-2-0)\end{array}$ & $\begin{array}{l}\mathrm{P}, \mathrm{D} \\
\mathrm{P}, \mathrm{D}\end{array}$ \\
\hline $\begin{array}{l}\text { Darts + secretions } \\
\text { shot from mating } \\
\text { snails }\end{array}$ & 0.6 & 3 & $\begin{array}{l}12 \mathrm{NS} \\
(1-4-6-1)\end{array}$ & $\mathrm{P}, \mathrm{D}$ \\
\hline \multicolumn{5}{|l|}{ Other tissues, boiled } \\
\hline Penis & 7.9 & 7 & $\begin{array}{l}4 * * \\
(1-3-0-0)\end{array}$ & $\mathrm{P}, \mathrm{D}$ \\
\hline Dart sac & 5.2 & 14 & $\begin{array}{l}2 * * \\
(1-1-0-0)\end{array}$ & $\mathrm{P}, \mathrm{D}$ \\
\hline $\begin{array}{l}\text { Mantle collar } \\
\text { Brain }\end{array}$ & $\begin{array}{l}6.8 \\
5.1\end{array}$ & $\begin{array}{l}5 \\
8\end{array}$ & $\begin{array}{l}0 * * \\
0 * *\end{array}$ & $\begin{array}{l}\mathrm{P} \\
\mathrm{P}, \mathrm{D}\end{array}$ \\
\hline \multicolumn{5}{|l|}{ Non-tissue injections } \\
\hline $\begin{array}{l}\mathrm{H}_{2} \mathrm{O} \text { or saline } \\
\text { Pronase (boiled) }\end{array}$ & - & 10 & $0 * *$ & NR \\
\hline $\begin{array}{l}\text { Pronase (boiled) } \\
\text { ACh }\end{array}$ & $\begin{array}{l}0.04-6.3 \\
5-50\end{array}$ & $\begin{array}{r}12 \\
7\end{array}$ & $\begin{array}{l}0 * * \\
0 * *\end{array}$ & $\begin{array}{l}\text { NR } \\
\mathrm{P}\end{array}$ \\
\hline 5-HT & $0.50-50$ & 5 & $0 * *$ & $\mathrm{P}$ \\
\hline
\end{tabular}

${ }^{a} \mathrm{P}=$ tetany and paralysis. $\mathrm{D}=$ some genital pore swelling. $\mathrm{NR}=$ no effect on behavior.

${ }^{\mathrm{b}} \mathrm{NS}=$ positive response not significantly smaller than positive response to boiled mucous gland (first entry). Fisher's exact test; 1 tailed, $\mathrm{P}>0.05$.

${ }^{c * *}=$ Positive response significantly smaller than response to boiled mucous gland extract (first entry). Fisher's exact test; 1-tailed, $\mathrm{P}<0.005$.

viscous to inject. The "standard concentration" (Sc) for the extracts and injections in this series was calculated so that the volume injected (Vi) would be $0.5 \mathrm{ml}$ for a $6.5 \mathrm{~g}$ snail. Thus, $\mathrm{Vi}=(\mathrm{Sd} / \mathrm{Sc}) \times$ weight of snail $=$ $(0.0769 \mathrm{ml} / \mathrm{g}) \times$ weight of snail in grams, for all tissue doses. A linear increase of $\mathrm{Vi}$ to snail weight seemed reasonable considering the fact that respiration has been found to be proportional to weight in helicids (see Ghiretti and Ghiretti-Magaldi, '75). The standard Vi was used for all snails of this bioassay series (which include all snails in Table 1).

Estimating an average blood volume of $50 \%(\mathrm{ml} / \mathrm{g}$ ) for $H$. aspersa (without shell) (see Machin, "75), and calculating the weight of the snail without shell from weight with shell (see Chung, ' 85 for regression), the Vi was estimated to be about $18 \%$ of the total blood volume of the injected snail. The standard $\mathrm{Vi}$ was used for all snails of the second bioassay series (which include all snails in Table 1). In order to make sure that injecting a relatively large volume of mucous gland extract into the snails did not cause any unusual response, a few snails were injected with onehalf volume of boiled mucous gland extract of twice the standard concentration (" $1 / 2$ volume," Table 1).

'To check that a bioassayable substance was being passed between courting snails by way of the dart, 15 snails were injected with a boiled extract of spent darts (with adhering mucous secretions) obtained from mating snails. The darts were collected after being shot from courting snails and were stored at $-29^{\circ} \mathrm{C}$ until ground for use. Snails were injected with a dose of approximately one ground dart in a $0.5 \mathrm{ml}$ solution. On average, a dart weighed $2 \mathrm{mg}$, and the adhering secretions, usually in the form of a whitish mucous globule, weighed about $2 \mathrm{mg}$. Since not all of the secretions from the mucous gland would be expected to enter through the dart 
wound, all injections of mucous gland secretions were probably equivalent to a maximum dose a snail might receive in courtship.

In order to check that the mucous glands were secreting mucus during courtship, the dry weights of mucous glands from snails recently mated (one to two days before) were compared to the weights of the glands from snails that had recovered from mating for at least five days. The glands and body (minus shell) were dried at $80^{\circ}$ to constant weight, the tissues weighed, and the gland to body weight ratio was compared for the two groups.

Attempted chloroform extraction of the active substance in the mucous gland extract involved mixing the crude homogenate in a vial with an approximately equal volume of chloroform. The chloroform fraction was then removed and boiled for about ten minutes to dryness and the brown residue resuspended in $\mathrm{H}_{2} \mathrm{O}$ and then injected ("chloroform fraction," Table 1). The remaining aqueous fraction was separately boiled for 15 minutes to rid it of traces of chloroform and then injected ("aqueous fraction," Table 1). Any precipitate formed by this process was not injected.

For protease digestion, Pronase (Type XIV, Sigma Chem. Co.) at a dose of 0.04 to $6.3 \mathrm{mg} /$ $\mathrm{g}$ was added to boiled mucous gland supernatant and incubated at room temperature for 15 minutes. The solution was then boiled for a second time for five minutes and then injected after cooling. Control solutions of of Pronase in $\mathrm{H}_{2} \mathrm{O}$ were incubated for 15 minutes, boiled for 5 minutes, and then injected after cooling. For nucleic acid digestion, both DNase I (Type III, Sigma) and RNase A (Type III, Sigma), both at doses of $3.6 \mathrm{mg} / \mathrm{g}$, were added to boiled mucous gland supernatant and incubated for 15 minutes at room temperature. The solution was then boiled for a second time for five minutes before injection. The $\mathrm{pH}$ of the mucous gland extracts was about $\mathrm{pH} 6.6$; no attempt was made to buffer it at $\mathrm{pH} 7$.

In addition to injections, unboiled mucous gland extracts were applied to the skin of five snails, and boiled mucous gland extract was applied to the skin of four snails. The same standard dose of $4.5 \mathrm{mg} / \mathrm{g}$ was used in these treatments, as in the injections, but the exract concentration was set to double and the volume delivered was set to half the standard values in order to facilitate topical application of the extracts.

\section{Interspecific injections}

'Ten Cepaea nemoralis, a related helicid, were injected with the standard boiled mucous gland extract of Helix aspersa, and five others were injected with boiled mantle collar extract of $H$. aspersa to see if the gland secretion could be used in species recognition between closely related helicids. Doses were the same as in Table 1, and Vi was calculated as above.

\section{Dilution series}

In order to determine the dose-response relationship for boiled mucous gland extract, a dilution series of the extract was made. The following dose levels (in multiples of the standard dose) and sample sizes were tested: $2 \times$ standard -5 snails, $1.5 \times-26$ snails, $1 \times-$ 30 snails, $0.75 \times-20$ snails, $0.5 \times-17$ snails, $0.25 \times-14$ snails, $0.125 \times-11$ snails. The Vi remained the same (calculated as above) for all dose levels.

\section{Gel filtration chromatography}

Mucous glands were dissected out of isolated snails and stored at $-29^{\circ} \mathrm{C}\left(-20^{\circ} \mathrm{F}\right)$. The glands were homogenized in distilled water in a glass tissue grinder with a machine driven Teflon pestle for five minutes to give a concentration of $0.117 \mathrm{~g}$ mucous gland/ $\mathrm{ml}$ solution. The extract was spun down at $190 \mathrm{~g}$ for ten minutes at $5^{\circ} \mathrm{C}$ to obtain a translucent supernatant. The supernatant was boiled in a water bath for five minutes. The boiled extract was frozen over a dry iceethanol bath and lyophilized overnight to give a residue of $0.0144 \mathrm{~g}$ mucous gland/1.0 $\mathrm{mg}$ lyophilate. A sample of $17.9 \mathrm{mg}$ of lyophilate was dissolved in $1.1 \mathrm{ml} 6.5 \times 10^{-5} \mathrm{M}$ acetic acid solution ( $\mathrm{pH} 4.85$ ) to give a concentration of about $0.235 \mathrm{~g}$ mucous gland $/ \mathrm{ml}$. This solution was centrifuged at $190 \mathrm{~g}$ for ten minutes at $5^{\circ} \mathrm{C}$ to clear it of part of the sediment.

The supernatant was layered on a $1.5 \times$ $17.0 \mathrm{~cm}$ Bio-Gel P.6 (medium grade, Bio-Rad) column equilibrated with the same acetic acid solution. Elution was performed with the same acetic acid solution at a flow rate of about $1 \mathrm{ml} / 17$ minutes. The column and eluate were kept at $4^{\circ} \mathrm{C}$ during the run. $\mathrm{Ab}$ sorbance of the eluate $(2 \mathrm{ml}$ per tube) was read at $280 \mathrm{~nm}$ with a Zeiss PMQ3 spectrophotometer. The eluate in each tube (tubes not pooled) was then used for injection into snails for assaying the active substance. 

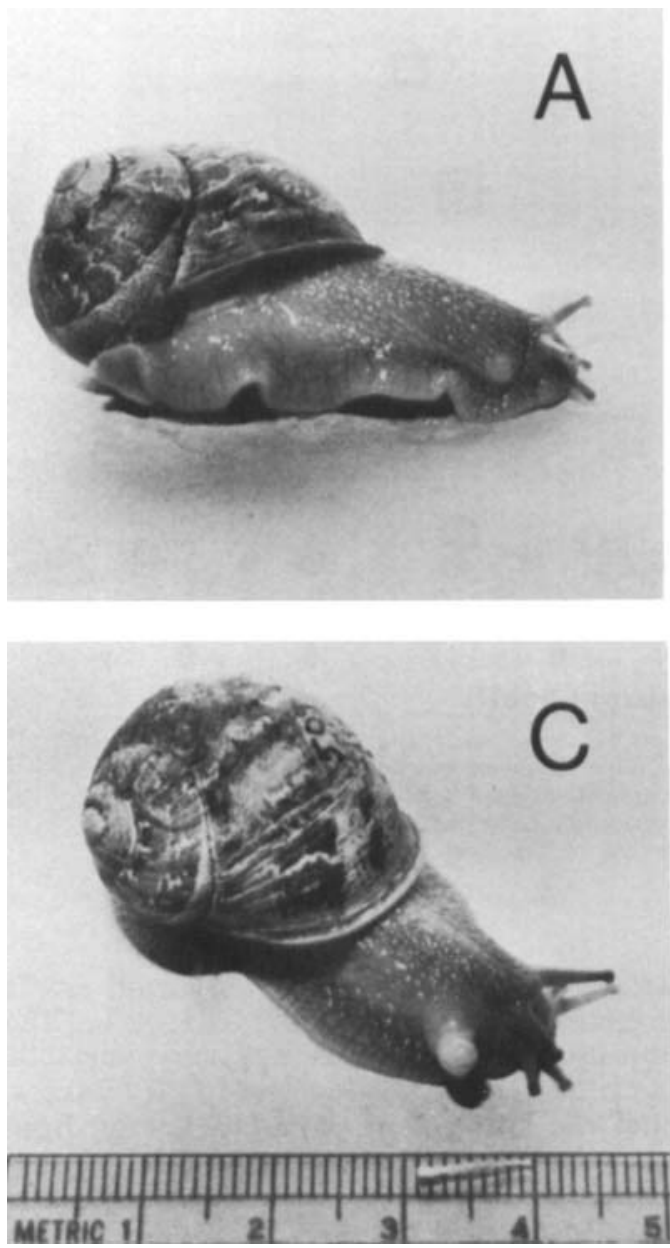

Fig. 1. Four adults of Helix aspersa showing varying degrees of genital eversion. A) Snail injected with unboiled mucous gland extract showing no genital eversion (R0) but with slight swelling of the genital pore. B) Snail injected with boiled mucous gland showing part of the penial lobe everted (R1). C) Normal courting snail separated from partner showing full eversion of the penial

From 0.5 to $1.0 \mathrm{Vi}$ was injected into assay snails. Tubes showing bioactivity were compared in their position to absorbance peaks $(280 \mathrm{~nm})$ of the following standards: Dextran Blue, ACTH, and Angiotensin I. Standards had been run on the same column with the same acetic acid solution.

\section{Scoring of responses to bioassays}

Responses of the snails to all bioassay injections and topical applications were re-
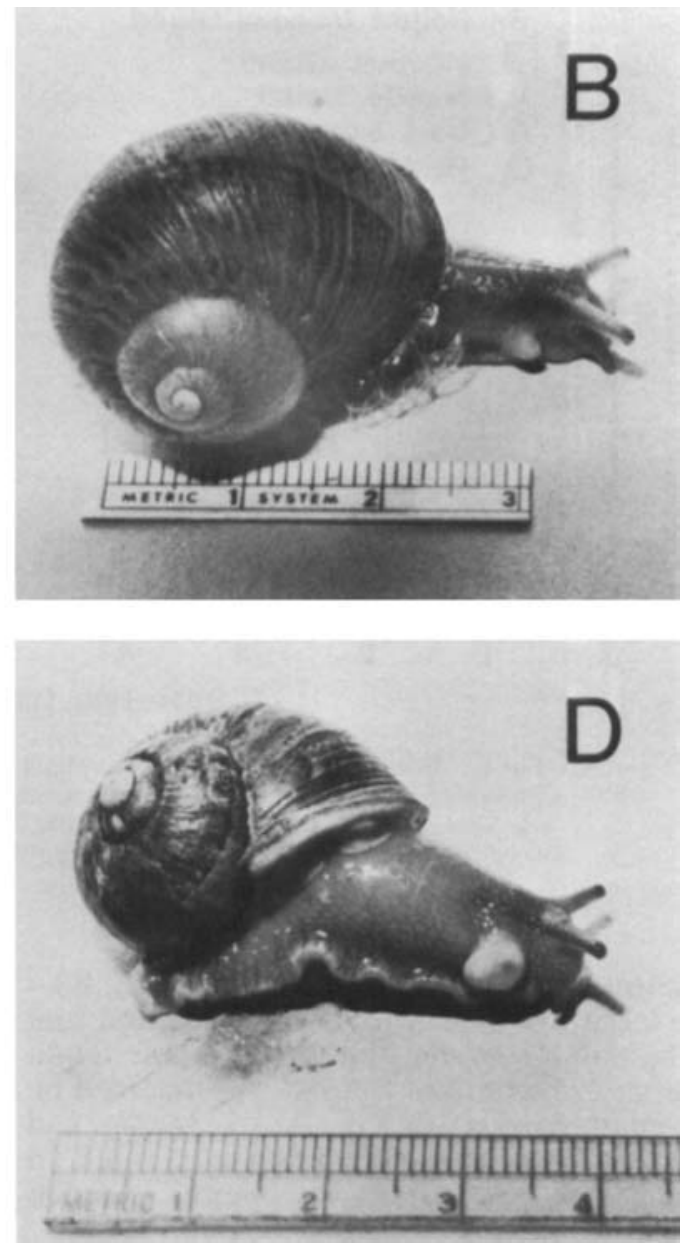

lobe (R2). The dart it received from its partner was removed and lies between the $3-\mathrm{cm}$ and $4-\mathrm{cm}$ marks on the ruler. D) Snail injected with boiled mucous gland extract with eversion showing the posterior male opening and the anterior female opening (R3). Rulers marked in centimeters.

corded in the same way. The snails were watched for eversion of the normally inverted terminal genitalia and for other unusual behavior for a minimum of 15 minutes after injection, or until recovery. Genital eversion was rated on a five-point scale: $\mathrm{RO}-$ either no response at all (NR), or a slight swelling of the genital pore (D), but without any eversion of a distinct lobe; $\mathrm{R} 1-\mathrm{a}$ small eversion of part of the penial lobe; $R 2-a$ moderate eversion of the entire penial lobe, 


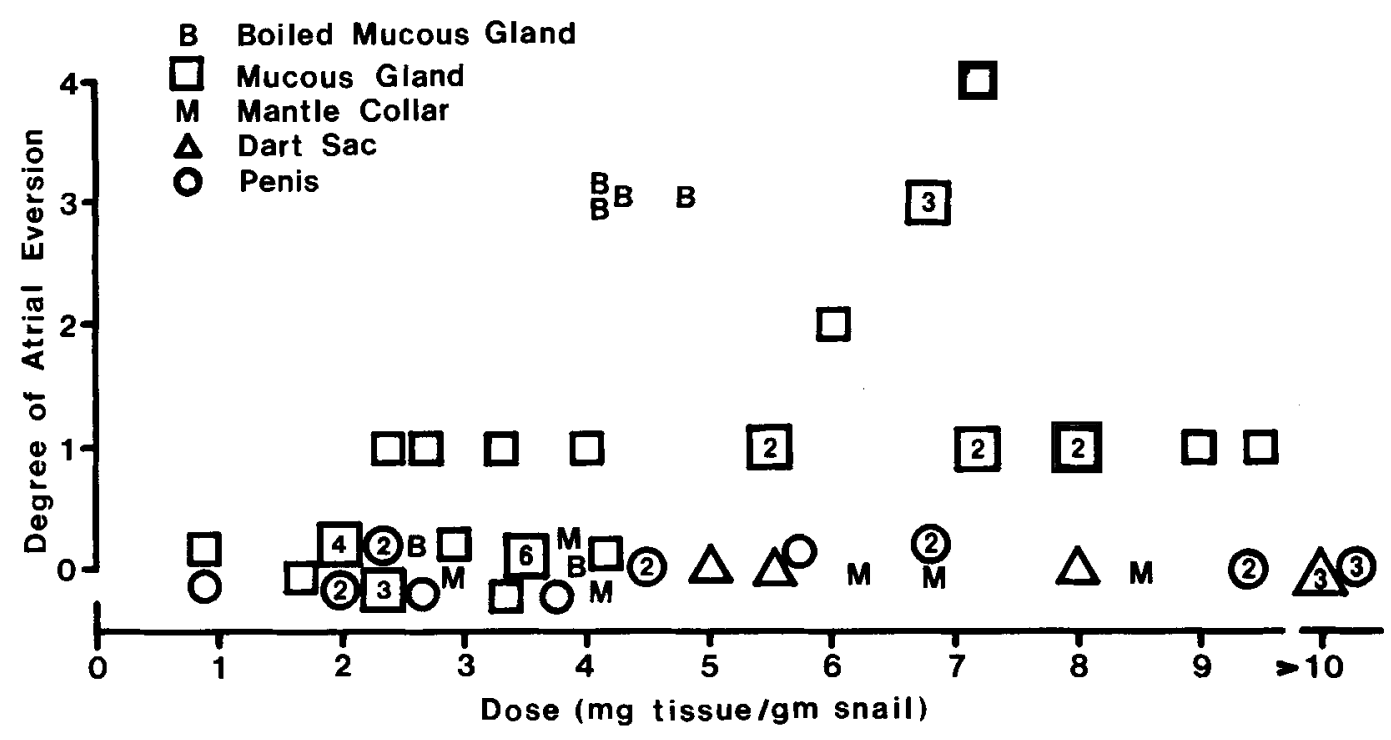

Fig. 2. Response of snails to mucous gland and other tissue extract injections. Each symbol represents one snail. Numbers inside the symbols indicate cases of two or more snails given the same dose and showing the same response. Only snails injected with the unboiled or boiled mucous gland extract showed responses of greater than zero (positive responses).

with the penial opening clearly visible; R3a large eversion, with both the penial and vaginal lobes showing clearly; and $\mathrm{R} 4-\mathrm{a}$ large eversion like R3, but accompanied by penial eversion (see Fig. 1). An eversion had to last for at least one minute to be rated. In normally courting snails, genital eversion could be rated in the same fashion.

\section{RESULTS}

Helix aspersa responded to injection of mucous gland and boiled mucous gland extracts by everting the genital atrium and sometimes also the penis. Examples of four different levels of response are shown in Figure 1. The snail in Figure 1C is a normal courting snail with an eversion of $R 2$, and with the dart it received from its partner removed to show its size relative to the snail. Normally courting snails usually show eversions as that shown in Figure 1D (R3). Snails injected with the boiled or unboiled mucous gland extract showed tensing of the body wall musculature, often with heavy mucous and fluid secretion and ruffling of the sole of the foot (designated as "tetany") (Figs. 1A, 1D). The snails then remained paralyzed even after the tetany subsided, and they slowly regained the ability to crawl again. A phase of tetany and paralysis occurred in all snails injected with mucous gland extract, but the duration of the phases was very variable, with the tetany lasting one to 10 minutes, and the subsequent paralysis lasting from three minutes to occasionally over one and one-half hours. Eversions lasted from $3 \mathrm{~min}$ utes to over 30 minutes, with most lasting for 5 to 10 minutes. Immature snails raised to maturity in isolation (probable virgins) often became "priapic" after injection with mucous gland extract, with eversions lasting for more than one day after recovery from paralysis.

\section{Preliminary assays}

Snails injected with unboiled penis, dart sac, and mantle collar tissue did not have eversions (Fig. 2), though unboiled penis and dart sac extract caused tetany and paralysis and some swelling of the genital pore. Unboiled mantle collar extract seemed to have no effect on the behavior of the snails, i.e. no tetany, paralysis, or genital pore swelling.

\section{Preliminary characterization of active substance}

There seemed to be a greater eversion response when the mucous gland extract was 
boiled (Fig. 2), and this was confirmed in the second series of bioassays (Table 1). A 1-tailed Fisher's exact test of independence between boiled and unboiled extract and their ability to cause eversion (response $>$ R0) was significant at $\mathrm{P}<0.005$. Pair-wise comparisons of other injections with injection of boiled $\mathrm{mu}$ cous gland extract (BMgl) using the same test showed that boiled penis, dart sac, mantle collar, and brain extracts were less effective at producing eversions than $\mathrm{BMgl}$. However, in contrast to the unboiled penis and dart sac extracts (Fig. 1), the boiled penis and dart sac extracts did cause some eversion. Also, boiled mantle collar extract caused some tetany and paralysis, unlike the unboiled extract.

Comparison of $\mathrm{BMgl}$ with $1 / 2$ volume $\mathrm{BMgl}$ showed that full volume $\mathrm{BMgl}$ was not more effective, and mere injection of a relatively large volume probably does not cause eversion in BMgl extract. Solutions of the neurotransmitters acetylcholine and 5-hydroxytryptamine caused no eversion or genital pore swelling but caused paralysis and subsequent uncoordinated movements and writhing. Snail saline and $\mathrm{H}_{2} \mathrm{O}$ injections had no effect on snail behavior.

Boiled extract of spent darts (plus adhering mucous) obtained from mating snails caused genital eversion undistinguishable from that of boiled mucous gland extracts (Table 1). The results of the injection of the extract of spent darts were found to be significantly different from that of extract of darts (plus dart sac tissue) dissected out of donor snails (Table 1) using a Fisher's exact test $(\mathrm{P}<$ $0.005,1$-tailed).

Mucous gland weights one to two days after courtship and mating were found to be significantly smaller than mucous gland weights in snails that had recovered from mating for at least five days. The ratio of dry mucous gland weight to dry body weight (minus shell ) was $0.0047+0.0011(\mathrm{n}=8)$ for recently mated snails and $0.0099 \pm 0.0026$ $(n=17)$ for snails recovered from mating. The difference is significant (Wilcoxon twosample test, 2 -tailed, $P<0.05$ ).

Comparison of BMgl with Pronase-treated and DNase + RNase-treated BMgl extract (Table 1) showed that Pronase inactivated the BMgl extract and DNase and RNase did not. Pronase-treated extract caused only minor genital pore swelling and some tetany and paralysis. The control Pronase solution had no effect on snail behavior.

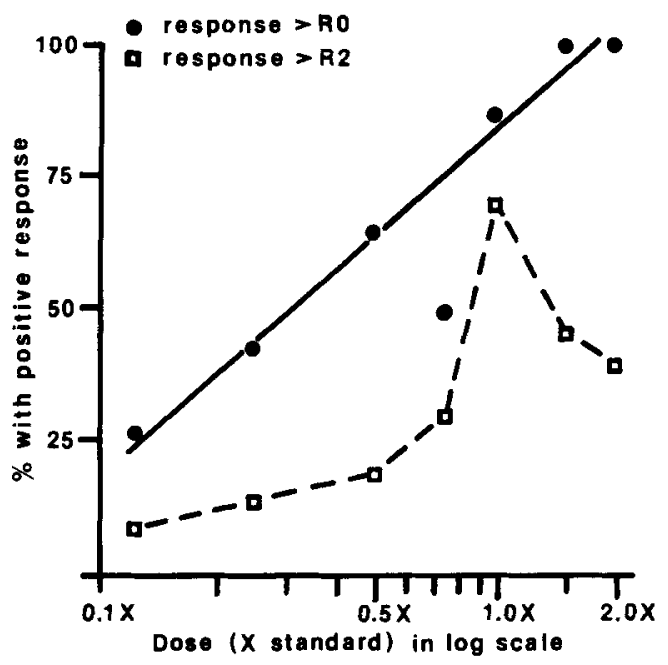

Fig. 3. Dose-response curve for snails injected with boiled mucous gland extract. Dose is given in multiples of the standard dose of $4.5 \mathrm{mg} / \mathrm{g}$ snail-the calculated average dose level. The percentages of all snails showing a positive response (greater than R0; solid circles) were fitted with a regression line: $\mathrm{Y}=62.95 \times \log _{10}($ dose $)$ $+80.43, r=0.93$. Each data point represents the percent responding in a single sample of from 11 to 30 snails injected (see text). Plot of snails showing eversion of R3 and R4 (squares) show that snails respond best when given the average mucous gland dose. Higher than normal doses produced suboptimal responses.

A chloroform extract of mucous gland gave a negative response (no eversion); it caused pronounced paralysis but almost no genital pore swelling. the aqueous fraction gave a response that was not significantly smaller than that for plain BMgl.

Boiled and unboiled mucous gland extract did not cause eversion, genital pore swelling, or tetany and paralysis when applied to the skin of Helix aspersa. The snails, in fact, seemed to eat the mucous gland extract.

\section{Dilution series}

Figure 3 (solid circles) is a dose-response curve showing the percentage of positive re. sponses (response $>\mathrm{R} 0$ ) to $\mathrm{BMgl}$. If one unit of activity is defined as that which will induce positive responses in $50 \%$ of a group of assay snails, then crude boiled mucous gland extract from a single average donor (average $\mathrm{Mgl}$ wt is $28 \mathrm{mg}$ ) yields three units of activ. ity. If only large eversions were counted (Fig. 3 , squares), the greatest percent response was found at the standard dose, and the response dropped off at both higher and lower doses. 


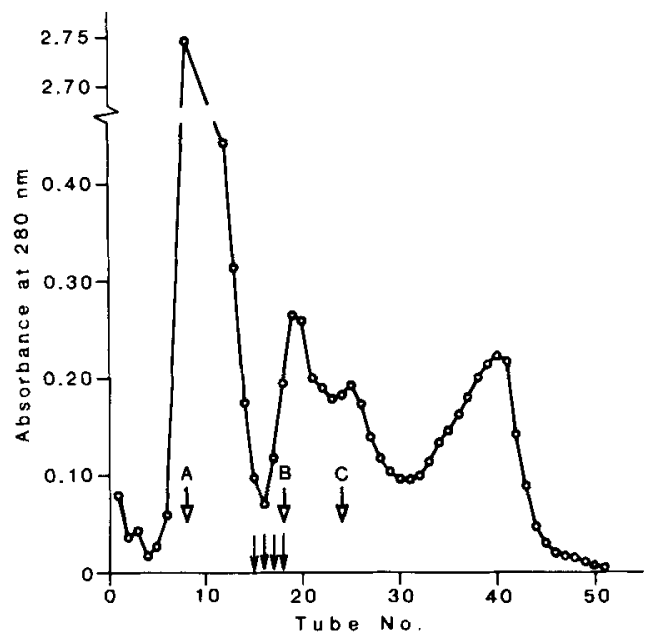

Fig. 4. Elution profile from gel filtration of boiled mucous gland extract. The four small arrows show each of the four tubes with bioactivity-tubes 15 to 18 . The three large arrows show the position of the absorption peaks for the standards Dextran Blue (A), ACTH (B), and Angiotensin I (C). The bioactive fraction falls behind the void volume (MW $>6,000$ ) and just before ACTH (MW about 4,700); this indicates a MW of about 5,000 for the bioactive substance. Each tube equals $2 \mathrm{ml}$ of eluate.

Snails injected with the $2 \times \mathrm{BMgl}$ showed a more pronounced tetany and paralysis than snails receiving the $1 \times$ solution, and these snails often delayed everting their genitals until 15 minutes after the injection, when they started to come out of tetany. By contrast, snails receving the $1 \times \mathrm{BMgl}$ usually everted within five minutes after injection.

\section{Interspecific injections}

Eight of ten Cepaea nemoralis injected with BMgl from $H$. aspersa gave positive responses (one R1, four R3, three R4). The five C. nemoralis injected with boiled mantle collar extract of $H$. aspersa showed tetany and paralysis but no eversion (five R0).

\section{Gel filtration chromatography}

The elution curve for substances absorbing at $280 \mathrm{~nm}$ is shown in Figure 4. Gel filtration of BMgl resulted in only four tubes (15-18) showing positive responses of $>$ R0 (Fig. 4, arrows), and only one other tube (14) which gave any genital pore swelling. In snails showing a positive response, eversion was accompanied by some tetany and paralysis, just as in snails injected with crude BMgl, but with smaller intensity and duration. The responses were: three snails-R1, two snailsR2. Injection of the contents of other tubes caused no effect on snail behavior; two tubes caused pronounced irritation (withdrawal into shell-tubes 10, 11). From comparison with the standards run through the column, the molecular weight of the active substance is between 4,700 and 6,000 . The active substance elutes close to the absorption peak for ACTH but after the void volume, and may have a MW of around 5,000. The active fractions do not correspond to a major absorbance peak at $280 \mathrm{~nm}$, perhaps due to the small amount of sample run through the column.

\section{DISCUSSION \\ Function of mucous gland secretion}

The results of this study are consistent with the hypothesis that there is a pheromone in the mucous gland secretion that gains entrance into the body of a snail through the dart wound and facilitates prolonged eversion and therefore receptivity. The active substance does not appear to occur in the nongenital tissues studied and may be found only in significantly smaller quantities in other genital tissues. The substance needs to be injected to induce eversion; application of mucous gland extract to the skin causes neither eversion nor paralysis. Snails will eat the mucous gland extract applied to their skins-a result also obtained by Dorello ('25). Pricking the skin of Helix aspersa with old, dried, discarded darts does not cause genital eversion (personal observation).

Normally courting snails of this species have genital eversions that are undistinguishable in appearance from genital eversions elicited by injection of mucous gland extract. Darted snails slow their rate of crawling, though they do not usually show paralysis as pronounced as that in snails injected with extracts.

The positive response to injection of boiled extract of darts (plus adhering secretions) obtained from mating snails and the decrease in the mucous gland to body weight ratio after mating are both consistent with Dorello's ('25) hypothesis that darts transfer active mucous gland secretions at the time of dart shooting. The significantly smaller response obtained from the bioassay of darts dissected from dart sacs compared to that of darts shot naturally from mating snails suggests that the mucous gland secretions are the major 
active substance eliciting the genital eversion seen in these experiments.

These observations do not support the conclusions of Lind ('76), Jeppesen ('76), and Giusti and Lepri ('80), who believed that dart receipt in $H$. pomatia and $H$. aspersa did not have a stimulatory effect. Lind ('76) and Jeppesen ('76) believed that the behaviors of $H$. pomatia during courtship and mating were mostly controlled by internal motivation, since they found little induced changes in frequency and timing of most courtship behaviors that appeared to be related to what the mating partner did. Jeppesen ('76) found no influence, and Lind ('76) found a somewhat negative influence on the completion of courtship by a snail's receipt of a dart. The exact reasons for the discrepancies between their findings and the findings reported in this paper are unknown. However, it can be speculated that since darting in Helix occurs after initial genital eversion and only during the middle of courtship, it might have been difficult for Lind and Jeppesen to notice any change in eversion or increase in receptivity in any snail that received a dart and then resumed courtship.

The results of the injections in this study are somewhat different from the assays of mucous gland extract or secretion done by Dorello ('25) and Goddard ('62) on H. aspersa. Goddard ('62) used a concentration of $0.024 \mathrm{~g}$ mucous gland $/ 100 \mathrm{ml}$ solution and found no effect on a penis sheath preparation. Goddard's concentration was, however, about 240 times smaller than the standard concentration used in this study $(0.0585 \mathrm{~g} \mathrm{Mgl} / \mathrm{ml})$, and this small concentration may explain lack of observed effects. Dorello ('25) appears to have injected small amounts of pure mucous gland secretion (dose unreported); this caused contortions in the snails and contractions of the body wall musculature, which were similar to the body wall contractions and tetany found in this study.

Boiling the mucous gland extract increased its activity significantly. Boiling may perhaps destroy a protease, inactivate an inhibitor of the active substance, or boiling may mimic a final activating step of the active substance in the cells of the mucous gland.

The resistance of the active substance to boiling, its solubility in water and insolubility in chloroform, its inactivation by Pronase, its stability in the presence of DNase and RNase, and its high molecular weight of approximately 5,000 suggest that it is a poly- peptide. Extracts of Aplysia bag cells found to have similar properties that suggested that the active substance was a polypeptide (Toevs and Brackenbury, '69; Kupfermann, '70). The actual secretory granules in the mucous gland cells of Helix pomatia have been found to contain small glycoprotein particles surrounded by acid and sulfated mucopolysaccharides (Bornchen, '67; Hollande, '66, '70).

The mechanism by which genital eversion is effected in normal snails during courtship is unknown; thus it cannot be compared with induced eversion by injection of mucous gland extract. However, it is believed that extrusion of the headfoot and head of Helix and other pulmonate snails occurs through an increase in the hemocoelic pressure caused by step-wise filling of the lung with air and contractions of the diaphragm (lung floor) and by a subsequent redistribution of the blood to the anterior aorta (Dale, '74; also see Jones, '75). The results of this study suggest that the active substance in the gland extract induces contraction of body wall muscles and a simultaneous relaxation of muscles of the genital pore and atrium; the rising hydrostatic pressure in the hemocoel may be the force that pushes the genitals out. In normally courting Helix, the snails do not contract their body walls greatly, except during dart shooting, but genital eversion is accompanied by a mid-sagittal crease of the sole of the foot beneath the head (personal observations), which might increase blood pressure in the head region. The tetany and paralysis evoked by nongenital tissue injections and other control injections might be completely unrelated to the muscle contractions induced by the mucous gland substance, since they do not produce eversions.

\section{Adaptive significance of darts}

The adaptive significance and evolution of the dart apparatus will be discussed elsewhere, but a few points can be made here. The results of injections of Helix aspersa mucous gland exract into Cepaea nemoralis indicate that the mucous gland secretions might not be used in species recognition. If the dart apparatus were used for species recognition, injection of $H$. aspersa mucous gland extract would be expected to prevent or be unable to cause genital eversion in Cepaea nemoralis.

The results of this study indicate that the dart may be used for traumatic inoculation of the mating partner with a contact phero- 
mone that enhances sexual receptivity in the courting partner. Outside of the mollusks, inoculation of a contact pheromone into a mating partner through teeth wounds has been hypothesized to occur in plethodontid salamanders (see Arnold, '76); but this hypothesis has not yet been proven (Arnold and Houck, '82). Accessory sexual organs composed of hardened papillae and associated glands are found in flatworms (e.g. prostatoids, see Hyman, '51) and have been assumed to have a "stimulatory" function, though experimental evidence for this assumption is lacking.

Experimental evidence for secretion of a contact pheromone in a pulmonate land snail has been obtained for one other species. Takeda and Tsuruoka ('79) found that the head wart in the land snail Euhadra peliomphala secreted a pheromone that elicited courtship behavior. This pheromone does not appear to be dispersed through the air; it is applied to the skin of the partner and appears to elicit genital eversion in the partner. Euhadra also has a dart apparatus, though its function has not been determined. The Euhadra head wart may elicit initial eversion, while the Helix dart apparatus may, in effect, increase eversion in a physiologically receptive snail. Growth of both the Euhadra head wart and $H$. aspersa mucous glands is dependent on a hormone (possibly a steroid) from the ovotestis (Takeda, '80; Gomot and Colard, '85).

The findings of this study indicate that other accessory organs in the terminal genitalia of pulmonate snails (see Tompa, '84 for review) may secrete pheromones. In the opisthobranchs, behavioral studies suggest the existence of sex pheromones (see Audesirk, '77), but a genital organ may perhaps be implicated in only one case-the atrial gland. Much work has been done on the atrial gland hormone of Aplysia; however, there is some confusion on which of the mating partners is stimulated by the secretions of this organ (see Arch et al., '80; Blankenship et al., '83), so that the exact significance of the hormone has not yet been determined. However, it is possible that the atrial gland and perhaps other accessory organs in the terminal genitalia of opisthobranchs (e.g. vestibular glands) (see Pruvot-Fol, '60) secrete pheromones.

\section{ACKNOWLEDGMENTS}

I would like to thank Dr. Alex Tompa for the support I received from him during my work on Helix aspersa and for sharing with me his knowledge on land snails. I would also like to thank Drs. Alex Tompa, Norman Kemp, James Cather, and Brian Hazlett for comments on the manuscript. I am grateful to Dr. Byron Doneen for providing technical advice and use of chromatographic equipment. This work was supported in part with grants from the University of Michigan and a grant from the Hawaiian Malacological Society.

\section{LITERATURE CITED}

Arch, S., J. Lupatkin, T. Smock, and M. Beard (1980) Evidence for an exocrine function of the Aplysia atrial gland. J. Comp. Physiol. 141:131-137.

Arnold, S.J. (1976) The evolution of courtship behavior in new world salamanders, with some comments on old world salamanders. In: The Reproductive Biology of Amphibians. D.H. Taylor and S.I. Gutman, eds. Plenum Press, New York, pp. 141-183.

Arnold, S.J. and L.D. Houck (1982) Courtship pheromones: Evolution by natural and sexual selection. In: Biochemical Aspects of Evolutionary Biology. M.H. Nitecki, ed. University of Chicago Press, Chicago, pp. 173-211.

Audesirk, T.E. (1977) Chemoreception in Aplysia californica III. Evidence for pheromones influencing reproductive behavior. Behav. Biol. 20:235-243.

Blankenship, J.E., M.K. Rock, L.C. Robbins, C.A. Liv. ingston, and H.K. Lehman (1983) Aspects of copulatory behavior and peptide control of egg laying in Aplysia. Federation Proc. 42:96-100.

Bohuslav, P. (1933) Die Gewebezüchtung des postembryonalen Verdauungstraktus, der Glandula salivalis and des Receptaculum seminis bei mollusken aus der Familie Helicidae. Arch. Exp. Zellforsch. Besonders Gewebezücht. 13:673-708.

Bornchen, M. (1967) Untersuchungen zur Sekretion der fingerformigen Drusen von Helix pomatia Z. Zellforsch. Mikrosk. Anat. 78:402-426.

Boss, K.J. (1982) Mollusca. In: Synopsis and Classification of Living Organisms. S.P. Parker, ed. McGrawHill, New York, pp. 945-1166.

Chung, D. (1985) An anesthetic for internal operations on the land snail Helix aspersa Müller. Veliger 27:331335.

Cooke, A.H. (1895) Molluses. In: Cambridge Natural History. S.F. Harmer and A.E. Shipley, eds. Macmillan and Co., New York, Vol. III, 535 pp.

Dale, B. (1974) Extrusion, retraction and respiratory movements in Helix pomatia in relation to distribution and circulation of the blood. J. Zool. Lond. 173:427439.

Diver, C. (1940) The problem of closely-related species living in the same area: In: The New Systematics. J.S. Huxley, ed. Clarendon Press, Oxford, pp. 303-328.

Dorello, P. (1925) Sulla funzione della glandole digitate nel Gen. Helix. Atti della Reale Acad. Naz. Dei Lincei, Ser. 6, Rendiconti, Cl. Sci. Fisiche, Matemat. Nat. 1:4751 .

Ghiretti, F. and A. Ghiretti-Magaldi (1975) Respiration. In: Pulmonates.V. Fretter and J. Peake, eds. Academic Press, New York, Vol. 1, pp. 33-52.

Giusti, F. and A. Lepri (1980) Aspetti morphologici ed etologici dell' accoppiamento in alcune specie della famiglia Helicidae (Gastropoda, Pulmonata). Atti Accademia Fisiocritici Siena (1980):11-71.

Goddard, C.K. (1962) Function of the penial apparatus of 
Helix aspersa. Austr. J. Biol. Sci. 15:218-232.

Gomot, L. and C. Colard (1985) Étude du contrôle de l' activité sécrétrice des glandes multifides par castration et greffe chez l'escargot Helix aspersa. Gen. Comp. Endocrinol. 58:159-168.

Hollande, E. (1966) Présence de mucopolysaccharides neutres et acides coincidant avec l'appareil de Golgi, dans les glandes multifides d'Helix pomatia C.R. Acad. Sc. Paris 262:1788-1791.

Hollande, E. (1970) Les glycoprotéines de l'appareil de Golgi et la formation des grains de sécrétion au cours de la réactivation expérimentale des glandes multifides de l'escargot Helix pomatia (L). C.R. Acad. Sc. Paris 270(D):3111-3114.

Hyman L.H. (1951) The invertebrates. Platyhelminthes and Rhynchocoela. McGraw-Hill, New York, Vol. II.

Jeppesen, L.L. (1976) The control of mating behaviour in Helix pomatia. Anim. Behav. 24:275-290.

Jones, H.D. (1975) Locomotion: In: Pulmonates. V. Fretter and J. Peake, eds. Academic Press, New York, Vol. 1, pp. 1-32.

Kerkut, G.A. and G.A. Cottrell (1963) Acetylcholine and 5 -hydroxytryptamine in the snail brain. Comp. Biochem. Physiol. 8:53-63.

Kupfermann, I. (1970) Stimulation of egg laying by extracts of neuroendocrine cells (bag cells) of abdominal ganglion of Aplysia. J. Neurophysiol. 33:877-881.

Lind, H. (1976) Causal and functional organization of the mating behavior sequence in Helix pomatia. Behaviour 59:162-202.

Machin, J. (1975) Water relationships. In: Pulmonates. V. Fretter and J. Peake, eds. Academic Press, New York, Vol. 1, pp. 105-163.
Meisenheimer, J. (1907) Biologie, Morphologie und Physiologie des Begattungsvorganges und der Eiablage von Helix pomatia. Zool. Jb. 25:461-502.

Meisenheimer, J. (1912) Die Weinbergschnecke. Leipzig. Moquin-Tandon, A. (1855) Histoire Naturelle des Mollusques Terrestres et Fluviatiles de France. Balliére, Paris.

Pruvot-Fol, A. (1960) Les organes génitaux des opisthobranches. Arch. Zool. Exp. Gen. 99:135-224.

Roach, D.K. (1963) Analysis of the hemolymph of Arion ater L. (Gastropoda: Pulmonata). J. Exp. Biol. 40:613623.

Takeda, N. (1980) Hormonal control of head-wart development in the snail. Euhadra peliomphala. J. Embryol. Exp. Morph. 60:57-69.

Takeda, N. and H. Tsuruoka (1979) A sex pheromone secreting gland in the terrestrial snail, Euhadra peliomphala. J. Exp. Zool. 207:17-26.

Toevs, L.A. and R.W. Brackenbury (1969) Bag cell-specific proteins and humoral control of egg laying in Aplysia californica Comp. Biochem. Physiol. 29:207216.

Tompa, A. (1980) The ultrastructure and mineralogy of the dart from Philomycus carolinianus with a brief survey of the occurrence of darts in land snails. Veliger 23:35-42.

Tompa, A. (1984) Land snails. In: The Mollusca, Vol. 7, Reproduction. A. Tompa, N.H. Verdonk, and J.A.M. van den Biggelaar, eds. Academic Press, New York, pp. 47-140.

Webb, G.R. (1951) An instance of amixia between two species of land snails. Am. Nat. 85:137-139. 